\title{
Long term follow up after inhalation of foreign bodies
}

\author{
H Davies, I Gordon, D J Matthew, P Helms, I J Kenney, J E Lutkin, W Lenney
}

\begin{abstract}
The long term results of treatment of inhalation of foreign bodies in a district children's hospital and in a tertiary referral centre were reviewed by clinical assessment, chest radiography, and standard four view ${ }^{81 m} \mathbf{K r}$ ventilation ${ }^{99 \mathrm{~m}} \mathrm{Tc}$ macroaggregated albumin perfusion imaging (V/Q lung scan). The overall incidence in the population served by the district hospital was roughly one in 14000 / year. Of the 12 children reviewed there, three had abnormal chest radiographs and four had abnormal V/Q scans as a result of inhalation of the foreign bodies. Of 21 children treated and reviewed at the referral centre, eight had abnormal chest radiographs, and 14 had abnormal V/Q lung scans. Three factors were assessed for prognostic importance: site of impaction, initial radiographic appearance, and time before removal. A child who had inhaled a foreign body into the left lung and who had collapse/consolidation on the initial chest radiograph was at greatest risk of long term complications. These children merit close follow up.
\end{abstract}

The incidence of inhalation of foreign bodies reaches a peak in infancy and early childhood, which is a time when the lungs grow rapidly and when any appreciable insult might be expected to cause irreversible lung damage. Abdulmajid et al reported 15 long term complications (recurrent pneumonia: $n=12$, abscess: $n=1$, and bronchiectasis: $n=2$ ) in 250 children followed up after inhalation of foreign bodies. ${ }^{1}$ They associated the complications with delay in its removal. Despite this possibility, most studies have concentrated on the immediate rather than the long term consequences using clinical examination and chest radiography alone. ${ }^{23}$ In this way they will probably detect only the most severe complications such as bronchiectasis, McCleod's syndrome, and persistent collapse or consolidation.

As a reliable picture of regional pulmonary ventilation and perfusion can only be achieved non-invasively by ${ }^{81 \mathrm{~m}} \mathrm{Kr}$ ventilation ${ }^{99 \mathrm{~m}} \mathrm{Tc}$ macroaggregate albumin perfusion imaging (V/Q lung scan) the complications of the inhalation of foreign bodies at a district hospital (Royal Alexandra Hospital) and a tertiary referral centre (Hospital for Sick Children, Great Ormond Street) were reviewed by clinical assessment, chest radiography, and V/Q lung scan. Puterman et al have clearly shown the value of an educational programme for medical staff to heighten their awareness of the effects of inhalation of foreign bodies. ${ }^{4}$ Further identification of adverse prognostic features should enable those children who are most at risk of long term complications to be followed up. The aim of the study at the district hospital was to determine the incidence both of inhalation of foreign bodies and the consequences in a geographically defined population. The data from the tertiary referral centre (which might be expected to deal with more complicated cases) was used to identify the number of children with persisting lung damage and to establish which were the adverse prognostic factors.

\section{Patients and methods}

Children with bronchoscopically diagnosed inhaled foreign bodies were identified from theatre records, discharge diagnoses, and ward admission books in both hospitals; all such cases were invited for review, which comprised clinical assessment, chest radiography, and V/Q lung scan. Clinical details of presentation and subsequent treatment were obtained from the medical notes, together with the chest radiographs that had been taken before removal of the foreign body. Ethical committee approval was obtained for the study.

Chest radiographs were reviewed according to the recommendations of the European Society of Paediatric Radiology. ${ }^{5}$ Each lobe was defined as normal, emphysematous, collapsed, or collapsed/consolidated. On the V/Q scans, areas of hypoperfusion or hypoventilation were identified by inspection of the steady state image. Statistical analysis was by $\chi^{2}$ test with Yates's correction.

\section{DISTRICT HOSPITAL}

The diagnosis was made in 25 children ( 19 boys and six girls, median age 2.0 years), between 1977 and 1986, of whom 12 returned for review (table 1). The median age at presentation of those followed up ( 1.8 years) was slightly less than those who were not $(2 \cdot 3$ years). It is unlikely that cases from this district would be treated at any other hospital, no other has facilities for paediatric bronchoscopy. Some may have been referred from health districts around Brighton, however, in which case the figure may be an over estimate. Ward admission books were reviewed to ensure that all cases were included.

TERTIARY REFERRAL CENTRE

Twenty six children were treated between 1979
Department of Paediatrics, Central Middlesex Hospital,

London NW10 7NS.

Accepted 31 January 1990 
Table 1 Children studied at district hospital

\begin{tabular}{|c|c|c|c|c|c|c|c|c|}
\hline \multirow{2}{*}{$\begin{array}{l}\text { Age } \\
\text { (years) }\end{array}$} & \multirow[t]{2}{*}{ Sex } & \multirow{2}{*}{$\begin{array}{l}\text { Type } \\
\text { of foreign } \\
\text { body }\end{array}$} & \multirow{2}{*}{$\begin{array}{l}\text { Site } \\
\text { (lung) }\end{array}$} & \multirow{2}{*}{$\begin{array}{l}\text { No of days } \\
\text { before removal }\end{array}$} & \multirow{2}{*}{$\begin{array}{l}\text { Result of } \\
\text { initial chest } \\
\text { radiograph }\end{array}$} & \multirow{2}{*}{$\begin{array}{l}\text { Result of } \\
\text { follow up } \\
\text { chest } \\
\text { radiograph }\end{array}$} & \multicolumn{2}{|c|}{ Result of $V / Q$ lung scan } \\
\hline & & & & & & & Left & Right \\
\hline $\begin{array}{l}0 \cdot 6 \\
1 \cdot 0 \\
1 \cdot 1 \\
1 \cdot 3 \\
1 \cdot 3 \\
1 \cdot 3 \\
1 \cdot 4 \\
1 \cdot 6 \\
1 \cdot 8 \\
1 \cdot 8 \\
2 \cdot 0 \\
2 \cdot 0 \\
2 \cdot 1 \\
2 \cdot 2 \\
2 \cdot 3 \\
2 \cdot 5 \\
2 \cdot 9 \\
3 \cdot 0 \\
3 \cdot 0 \\
3 \cdot 5 \\
5 \cdot 8 \\
6 \cdot 0 \\
8 \cdot 0 \\
9 \cdot 0 \\
\text { Not recorded }\end{array}$ & $\begin{array}{l}\text { Male } \\
\text { Male } \\
\text { Female } \\
\text { Female } \\
\text { Male } \\
\text { Female } \\
\text { Male } \\
\text { Male } \\
\text { Male } \\
\text { Male } \\
\text { Male } \\
\text { Male } \\
\text { Male } \\
\text { Male } \\
\text { Male } \\
\text { Male } \\
\text { Male } \\
\text { Male } \\
\text { Female } \\
\text { Male } \\
\text { Female } \\
\text { Female } \\
\text { Male } \\
\text { Male } \\
\text { Female }\end{array}$ & $\begin{array}{l}\text { Food } \\
\text { Apple } \\
\text { Wood } \\
\text { Nut } \\
\text { Nut } \\
\text { Nut } \\
\text { Nut } \\
\text { Potato } \\
\text { Pin } \\
\text { Peanut } \\
\text { Peanut } \\
\text { Nut } \\
\text { Nut } \\
\text { Nut } \\
\text { Carrot } \\
\text { Carrot } \\
\text { Melon seed } \\
\text { Nut } \\
\text { Screw } \\
\text { Plasticine } \\
\text { Pen cap } \\
\text { Pellet } \\
\text { Earring }\end{array}$ & $\begin{array}{l}\text { Left } \\
\text { Left } \\
\text { Right } \\
\text { Left } \\
\text { Right } \\
\text { Right } \\
\text { Left } \\
\text { Right } \\
\text { Left } \\
\text { Left } \\
\text { Right } \\
\text { Not reco } \\
\text { Right } \\
\text { Right } \\
\text { Right } \\
\text { Left } \\
\text { Right } \\
\text { Right } \\
\text { Right } \\
\text { Right } \\
\text { Right } \\
\text { Right } \\
\text { Right } \\
\text { Right }\end{array}$ & $\begin{array}{c}1 \\
1 \\
70 \\
14 \\
7 \\
1 \\
14 \\
1 \\
5 \\
1 \\
30 \\
\text { rded } \\
7 \\
3 \\
21 \\
2 \\
\text { Not recorded } \\
90 \\
1 \\
1 \\
2 \\
21\end{array}$ & $\begin{array}{l}\text { Normal } \\
\text { Hyperinflation } \\
\text { Collapse/consolidation } \\
\text { Hyperinflation } \\
\text { Collapse/consolidation } \\
\text { Collapse/consolidation } \\
\text { Collapse/consolidation } \\
\text { Hyperinflation } \\
\text { Not recorded } \\
\text { Collapse/consolidation } \\
\text { Hyperinflation } \\
\text { Normal } \\
\text { Normal } \\
\text { Hyperinflation } \\
\text { Collapse } \\
\text { Hyperinflation } \\
\text { Normal } \\
\text { Collapse/consolidation } \\
\text { Collapse } \\
\text { Collapse } \\
\text { Collapse } \\
\text { Collapse/consolidation } \\
\text { Not recorded } \\
\text { Collapse } \\
\text { Hyperinflation }\end{array}$ & $\begin{array}{l}\text { Abnormal } \\
\text { Normal } \\
\text { Normal } \\
\text { Abnormal } \\
\text { Normal } \\
\text { Normal } \\
\text { Normal }\end{array}$ & $\begin{array}{l}\text { Not recor } \\
\text { Not recor } \\
\text { Normal } \\
\text { Abnormal } \\
\text { Normal } \\
\text { Normal } \\
\text { Normal } \\
\text { Not recor } \\
\text { Abnormal } \\
\text { Not recor } \\
\text { Normal } \\
\text { Not recor } \\
\text { Not recorc } \\
\text { Normal } \\
\text { Not recorc } \\
\text { Normal } \\
\text { Not recorc } \\
\text { Abnormal } \\
\text { Not recorc } \\
\text { Not recorc } \\
\text { Not recorc } \\
\text { Normal }\end{array}$ & $\begin{array}{l}\text { ded } \\
\text { ded } \\
\text { Abnormal } \\
\text { Normal } \\
\text { Normal } \\
\text { Abnormal } \\
\text { Normal } \\
\text { ded } \\
\text { Normal } \\
\text { ded } \\
\text { Normal } \\
\text { ded } \\
\text { ded } \\
\text { Abnormal } \\
\text { ded } \\
\text { Normal } \\
\text { led } \\
\text { Abnormal } \\
\text { led } \\
\text { led } \\
\text { led } \\
\text { Normal }\end{array}$ \\
\hline
\end{tabular}

Table 2 Children studied at referral centre

\begin{tabular}{|c|c|c|c|c|c|c|c|c|c|}
\hline \multirow{2}{*}{$\begin{array}{l}\text { Age } \\
\text { (years) }\end{array}$} & \multirow[t]{2}{*}{ Sex } & \multirow{2}{*}{$\begin{array}{l}\text { Type of } \\
\text { foreign } \\
\text { body }\end{array}$} & \multirow{2}{*}{$\begin{array}{l}\text { Site } \\
\text { (lung) }\end{array}$} & \multirow{2}{*}{$\begin{array}{l}\text { No of } \\
\text { days } \\
\text { before } \\
\text { removal }\end{array}$} & \multirow{2}{*}{$\begin{array}{l}\text { Result of } \\
\text { initial chest } \\
\text { radiograph }\end{array}$} & \multirow[t]{2}{*}{ Symptoms } & \multirow{2}{*}{$\begin{array}{l}\text { Result of } \\
\text { follow up } \\
\text { chest } \\
\text { radiograph }\end{array}$} & \multicolumn{2}{|c|}{ Result of $V / Q$ lung scan } \\
\hline & & & & & & & & Left & Right \\
\hline $\begin{array}{l}1.0 \\
1.1 \\
1 \cdot 2 \\
1.3 \\
1.3 \\
1.3 \\
1.4 \\
1.5 \\
1.6 \\
1.6 \\
1.7 \\
1.9 \\
2 \cdot 0 \\
2.2 \\
2.2 \\
2.2 \\
2.4 \\
2.8 \\
2.9 \\
5.3 \\
5.7\end{array}$ & $\begin{array}{l}\text { Female } \\
\text { Male } \\
\text { Male } \\
\text { Male } \\
\text { Female } \\
\text { Female } \\
\text { Male } \\
\text { Male } \\
\text { Male } \\
\text { Male } \\
\text { Female } \\
\text { Male } \\
\text { Female } \\
\text { Male } \\
\text { Female } \\
\text { Male } \\
\text { Male } \\
\text { Male } \\
\text { Male } \\
\text { Male } \\
\text { Female }\end{array}$ & $\begin{array}{l}\text { Nut } \\
\text { Nut } \\
\text { Nut } \\
\text { Nut } \\
\text { Coal } \\
\text { Nut } \\
\text { Nut } \\
\text { Nut } \\
\text { Nut } \\
\text { Nut } \\
\text { Toy } \\
\text { Nut } \\
\text { Nut } \\
\text { Nut } \\
\text { Nut } \\
\text { Nut } \\
\text { Nut } \\
\text { Nut } \\
\text { Nut } \\
\text { Nut } \\
\text { Nut }\end{array}$ & $\begin{array}{l}\text { Right } \\
\text { Right } \\
\text { Right } \\
\text { Right } \\
\text { Left } \\
\text { Right } \\
\text { Right } \\
\text { Left } \\
\text { Right } \\
\text { Carina } \\
\text { Left } \\
\text { Right } \\
\text { Bilateral } \\
\text { Left } \\
\text { Left } \\
\text { Left } \\
\text { Left } \\
\text { Left } \\
\text { Left } \\
\text { Left } \\
\text { Left }\end{array}$ & $\begin{array}{r}6 \\
10 \\
30 \\
4 \\
150 \\
2 \\
1 \\
1 \\
14 \\
7 \\
28 \\
1 \\
1 \\
75 \\
2 \\
1 \\
21 \\
42 \\
21 \\
30 \\
120\end{array}$ & $\begin{array}{l}\text { Normal } \\
\text { Collapse } \\
\text { Hyperinflation } \\
\text { Hyperinflation } \\
\text { Hyperinflation } \\
\text { Collapse } \\
\text { Hyperinflation } \\
\text { Collapse } \\
\text { Hyperinflation } \\
\text { Hyperinflation } \\
\text { Hyperinflation } \\
\text { Hyperinflation } \\
\text { Normal } \\
\text { Collapse } \\
\text { Hyperinflation } \\
\text { Hyperinflation } \\
\text { Collapse } \\
\text { Collapse/consolidation } \\
\text { Hyperinflation } \\
\text { Hyperinflation } \\
\text { Collapse }\end{array}$ & $\begin{array}{l}\text { None } \\
\text { None } \\
\text { None } \\
\text { None } \\
\text { Cough } \\
\text { Cough and wheeze } \\
\text { None } \\
\text { None } \\
\text { Cough } \\
\text { None } \\
\text { None } \\
\text { None } \\
\text { None } \\
\text { Cough and wheeze } \\
\text { None } \\
\text { None } \\
\text { None } \\
\text { Wheeze } \\
\text { Cough and wheeze } \\
\text { Cough and wheeze } \\
\text { None }\end{array}$ & $\begin{array}{l}\text { Abnormal } \\
\text { Normal } \\
\text { Normal } \\
\text { Normal } \\
\text { Abnormal } \\
\text { Abnormal } \\
\text { Normal } \\
\text { Normal } \\
\text { Normal } \\
\text { Normal } \\
\text { Normal } \\
\text { Normal } \\
\text { Abnormal } \\
\text { Abnormal } \\
\text { Normal } \\
\text { Normal } \\
\text { Abnormal } \\
\text { Abnormal } \\
\text { Normal } \\
\text { Normal } \\
\text { Abnormal }\end{array}$ & $\begin{array}{l}\text { Normal } \\
\text { Abnormal } \\
\text { Normal } \\
\text { Normal } \\
\text { Abnormal } \\
\text { Abnormal } \\
\text { Normal } \\
\text { Abnormal } \\
\text { Abnormal } \\
\text { Normal } \\
\text { Abnormal } \\
\text { Normal } \\
\text { Abnormal } \\
\text { Abnormal } \\
\text { Normal } \\
\text { Abnormal } \\
\text { Abnormal } \\
\text { Abnormal } \\
\text { Abnormal } \\
\text { Abnormal } \\
\text { Abnormal }\end{array}$ & $\begin{array}{l}\text { Abnormal } \\
\text { Normal } \\
\text { Normal } \\
\text { Normal } \\
\text { Normal } \\
\text { Abnormal } \\
\text { Normal } \\
\text { Abnormal } \\
\text { Normal } \\
\text { Abnormal } \\
\text { Normal } \\
\text { Normal } \\
\text { Normal } \\
\text { Abnormal } \\
\text { Normal } \\
\text { Normal } \\
\text { Normal } \\
\text { Normal } \\
\text { Abnormal } \\
\text { Normal } \\
\text { Normal }\end{array}$ \\
\hline
\end{tabular}

and 1984 of whom 21 (14 boys and seven girls, median age 1.6 years, range 1.03 to 5.65 ) returned for review. Four could not be traced and one failed to attend (table 2).

\section{Results}

DISTRICT HOSPITAL

The diversity of objects inhaled by children treated at the district hospital contrasted with the findings at the tertiary referral centre (table 1 and 2). Foreign bodies were removed in less than seven days in 11 cases, and removal was delayed in 11. In three, the time before removal was not recorded. The foreign bodies were impacted in the right lungs in $16(64 \%)$ and in the left lungs in seven. The site of impaction was not recorded in two cases. The initial chest radiograph was normal in four $(16 \%)$, the classic picture of hyperinflation being seen in only seven $(28 \%)$. Collapse or collapse/consolidation was the most common radiographic appearance $(n=12,48 \%)$.

The mean length of follow up was 6.9 years. Of the 12 children reviewed, nine had normal radiographs at review and five had abnormal V/Q scans. Of these one had bilateral subsegmental defects compatible with bronchospasm. A clinical diagnosis of asthma had been made before review, and as there was no specific abnormality at the site of impaction of the foreign body this was regarded as normal for the purposes of this study. Thus four of 12 patients reviewed had abnormal scans.

\section{TERTIARY REFERRAL CENTRE}

Nineteen children had inhaled peanuts, one a piece of coal, and one a plastic peg. The foreign body was removed within a week in only 10 cases. In five it was removed between one and four weeks, but in six removal was delayed for longer than a month. One lodged in the carina, eight in the right lung, and 11 in the left. One child had fragments of peanuts removed from both lungs. Nine children each required more than one bronchoscopy to achieve complete removal.

Mean length of follow up for this group was 2.05 years, and at review 14 were symptom free. 
Of the other seven, two complained of persistent cough, one of wheeze, and four of cough and wheeze. Thirteen children had normal chest radiographs, but only seven had normal ventilation and perfusion in the lung in which the foreign body had been impacted. The overall incidence of abnormalities on $\mathrm{V} / \mathrm{Q}$ scan of the lung from which the foreign body had been removed was 14/21 (67\%). All children with normal scans had normal chest radiographs. The incidence of abnormalities on $\mathrm{V} / \mathrm{Q}$ scan was no higher in children reviewed earlier than the median length of follow. up (1.67 years), which suggested that the abnormalities seen on scans were persistent. Four of the 11 children reviewed before the median follow up (1.67 years) had normal V/Q scans, a similar proportion $(3 / 10)$ to those who were reviewed after 1.67 years.

The larger numbers and greater incidence of complications allowed us to see if there were any significant adverse prognostic factors, and impaction in the left lung was significantly related to the outcome when it was assessed by $\mathrm{V} / \mathrm{Q}$ lung scan $(\mathrm{p}<0.001)$. Although abnormalities were more likely if the initial chest radiograph had showed collapse/consolidation, or if removal of the foreign body was delayed, neither of the differences were significant.

Eleven of the 12 children who had had foreign bodies impacted in their left lungs had abnormal V/Q scans, but only three of the nine in whom they were lodged in the right lungs showed persisting abnormality. Collapse/ consolidation in the affected lung on the initial chest radiograph carried a worse prognosis than hyperinflation. Of seven children who had presented with lobar collapse or collapse/ consolidation, only one (14\%) had a normal V/Q scan at follow up. Twelve had presented with hyperinflation on the initial chest radiograph, and at follow up half had normal V/Q scans. Complications were more common if removal was delayed for longer than a week, and eight of 11 such children had abnormalities on their V/Q scans of the affected lungs.

\section{Discussion}

The data from the district paediatric hospital show that inhalation of a foreign body is not common. On average three cases a year were treated in the decade reviewed, and a junior doctor may see only one or two during a six month period of duty. The average paediatric population during this period was 41759 (Brighton Health District Information Office), which gives an incidence of roughly one in 13 920/year.

Medical staff may therefore not be familiar with the typical clinical features associated with inhalation of a foreign body, yet this study shows the importance of considering this diagnosis when children present with respiratory symptoms. It confirms the work of Williams and Phelan, ${ }^{6}$ who reviewed a group of 65 children in whom removal had been delayed from more than a week to find out the reason for the delay. They concluded that the diagnosis was often not considered, and it was not appre- ciated that inhalation of a foreign body may present with a wide variety of respiratory symptoms and signs. They also stated that some children with unexplained pulmonary symptoms may have inhaled foreign bodies particularly if they are older and more independent. We also confirm the report of Puterman et al, who demonstrated the value of a postgraduate educational programme to increase the awareness of this differential diagnosis. ${ }^{4}$

In the tertiary referral centre, the pattern of illness was different, and was not typical of the usual presentation of inhalation of a foreign body. The delayed referrals, predominance of impaction in the left lung, higher incidence of complications, and the necessity for several bronchoscopies for complete removal of the foreign bodies, support this. The high incidence of abnormalities in this group enabled identification of three adverse prognostic factors: impaction in the left lung, collapse/ consolidation on the initial chest radiograph, and delay in removal. The association between regional abnormalities of lung function and impaction in the left lung was significant $(\mathrm{p}<0.001)$.

The classical pattern of lobar hyperinflation and trapping of gas on expiration may not be seen on the initial radiograph. In an unselected group at the district hospital collapse/ consolidation was as common as hyperinflation. Most importantly, it is imperative to consider impaction in the left lung. Subtle signs of left lower lobe collapse/consolidation may be missed unless particularly sought. Although impaction in the right lung occurs more often, long term complications in this study were more common when the foreign body lodged in the left lung.

\section{CONCLUSIONS}

Inhalation of a foreign body may present with the radiographic picture of collapse/ consolidation rather than the classic appearance of air trapping.

Impaction of a foreign body in the left carries an increased risk of long term regional abnormalities of lung function. Such children merit close follow up to make sure that the abnormalities resolve and that clinical problems do not ensue.

We thank Sister E Wooler for help in tracing the patients' records at the Royal Alexandra Hospital for Sick Children, Brighton, and for discussing the study with patients and parents. Sister Wooler received a grant from the Royal Alexandra Hospital centenary fund. We thank our consultant colleagues for allowing us to enter their patients in the study.

1 Abdulmajid DA, Ebeid AM, Motaweh MM, Kleibo IS. Aspirated foreign bodies in the tracheal tree: report of 250 Aspirated foreign bodies in
cases. Thorax 1976;635:40.

2 Davis C. Inhaled foreign bodies in children. Arch Dis Child 1966;41:402-6.

3 Pyman C. Inhaled foreign bodies in childhood: a review of 230 Cases. Med $\mathcal{f}$ Aust 1971;114:62-8.

4 Puterman S, Gorodischer R, Leiberman A. Tracheobronchial foreign bodies: the impact of a postgraduate educational program on diagnosis, morbidity and treatment. Pediatrics 1982;70:96-8.

5 Piepsz A. Late sequelae of foreign body inhalation. A multicentre scintigraphic study. Eur $\mathcal{F}$ Nucl Med 1988;13: 578-81.

6 Williams HL, Phelan PD. The 'missed' inhaled foreign body in children. Med f Aust 1969;110:625-8. 